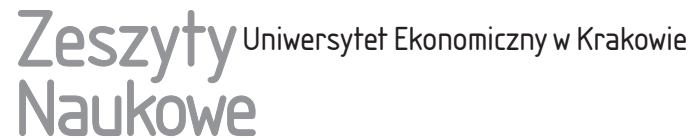

\section{Conditions for Innovation of Public Sector Organisations Based on Selected Primary Schools ${ }^{*}$}

\begin{abstract}
Objective: The aim of this article is to present and analyse the results of pilot studies relating to the diagnosis and evaluation of conditions for innovation of public sector organisations based on selected primary schools operating in a large city in Małopolskie Voivodeship, Poland.

Research Design \& Methods: The theoretical part of the article was based on the literature on the subject, both Polish and foreign. The pilot study was carried out by means of a guided, semi-structured interview with 17 teachers from four primary schools in Małopolskie Voivodeship, Poland. Undoubtedly, the results of the study have numerous limitations, which result mainly from the pilot nature of the survey and its limited scope (only selected teachers from four primary schools in a large city were willing to participate in the survey and were interviewed). Therefore, the results cannot be generalised and their analysis should be approached from a critical perspective.
\end{abstract}

Angelika Wodecka-Hyjek, Cracow University of Economics, College of Management and Quality Studies, Department of Management and Organization Methods, Rakowicka 27, 31-510 Kraków, e-mail: wodeckaa@uek.krakow.pl, ORCID: https://orcid.org/0000-0002-6930-4438.

* This publication presents the results of research project financed from the means granted to the Cracow University of Economics within the framework of the subsidy for the maintenance of research potential.

This is an open access article distributed under the terms of the Creative Commons Attribution-NonCommercial-NoDerivatives 4.0 License (CC BY-NC-ND 4.0); https://creativecommons.org/ licenses/by-nc-nd/4.0/ 
Findings: In the schools analysed, both the teachers and the management are aware of the importance of innovations in building the position of the school on the market of educational services, as well as of the fact that they are a key factor in teachers' personal development. The innovation policy in the schools was generally known, while teachers are inspired to seek and implement innovations, and the attitude of the management in the majority of cases stimulates the creativity of the teachers, which is additionally supported by tangible or intangible incentives, e.g. commendations or awards.

Implications/Recommendations: New ideas and solutions undoubtedly improve the teaching process, which is appreciated both by students and by their parents. In the primary schools participating in the study, the most important sources of innovation were the teachers, their level of knowledge, competence, creativity, commitment and personality. Contribution: Given the clear need for changes in the education sector, the study of innovation in primary schools is important and insufficiently recognised in Poland.

Keywords: innovation, public organisation, primary schools, guided interview. JEL Classification: O31, L31.

\section{Introduction}

To date, research on the characteristics of innovation have mainly centred on enterprises. However, current trends in the management of public sector organisations, such as New Public Management (e.g. Hood 1991) or Public Governance (e.g. Osborne 2006) allow for the assumption that innovative public sector organisations also form the basis for the development of modern economy. As the experiences of the business sector illustrate, innovative companies are flexible, open to technical and organisational progress, and have the ability to react quickly to market needs. A company's innovativeness depends on management's willingness to introduce innovative solutions and to offer conditions that are conducive to innovation (Zakrzewska-Bielawska 2011, p. 37).

These attributes are increasingly becoming desirable in primary schools, which are a specific type of public sector organisation. The literature on the conditions of innovation as well as solutions in this field has not been sufficiently recognised. The available studies highlight the need to imply innovation in the education sector, model the business sector, shape teacher-friendly characteristics for innovation and creativity, and stimulate interest in innovation. They also include attempts to classify innovation in education, as well as indicate the expectations of potential teachers as to the conditions necessary to develop innovation skills. These include: time, knowledge acquisition, institutional support and an appropriate evaluation system (including Klinger 2004, Mykhailyshyn, Kondur \& Serman 2018, Ciascai, S,uteu \& Cristea 2019, Vincent-Lancrin et al. 2019, Ayvaz Can 2020). With the need for change to occur in the education sector often today articulated, research on innovation conditioning in primary schools is equally important and insuf- 
ficiently recognised, within Poland and beyond. This article seeks to fill the research gap in this area.

This article presents and analyses the results of pilot studies relating to the diagnosis and evaluation of conditions for innovation in public sector organisations based on selected primary schools operating in a large city in Małopolskie Voivodeship, Poland. It provides examples of innovative solutions adopted in the schools examined. The first part of the article presents the conceptual model adopted in the study, developed on the basis of the subject literature, both Polish and foreign. The main part of the study presents the results of interviews with teachers from selected schools. The interviews were semi-structured and guided, designed to obtain the opinions of teachers on innovative measures implemented in the institutions where they were employed. The matters raised during the interviews included the motives for innovative measures, highlighting the areas of introduced changes (types of innovation), innovation policy with regard to initiating, generating and implementing innovations, and identifying barriers to innovation. Analysis of the material allowed for a preliminary identification of the conditions for innovation in the primary schools analysed. The research was a preliminary diagnosis of the problem under analysis, while the findings were not subjected to statistical analysis.

\section{The Nature of Innovation in the Public Sector}

The understanding of innovation in the subject literature is broad. In the classical theory of J. Schumpeter (1960, p. 104), innovation was defined as production and dissemination of new products and services, the application of new manufacturing technologies, seeking and mastering new sales markets, seeking and using new sources of raw materials supply and creating new organisational solutions in the economy. According to P. F. Drucker (1992, p. 42), who focused on its social aspects, innovation is a change in value and satisfaction of consumer needs through the use of specific resources. The basis for a modern interpretation of innovation is the methodology proposed by the OECD, where the general definition of innovation refers to all sectors of the economy, including the public sector, and states that innovation is a new or improved product or process (or a combination thereof) that is significantly different from the previous product or process, which has been made available to potential users (product) or put into use by an individual (process)" (OECD 2018, p. 60).

In the public sector, innovation is understood as an idea, practice or object perceived as new by an individual or organisation; as an adaptation of an existing idea for the first time by an organisation (De Vries, Bekkers \& Tummers 2016, p. 152), or as a new or significant changes in services, operational processes, organisational methods or ways of organising and communicating with the user 
(Bloch 2011, p. 13). It is also defined as a certain novelty - a product, service, structure or process that already exists, also in other areas of life, as a response to a new requirement or to an emerging social problem. A specific attribute of innovation in the public sector is the focus on the shape of services and methods of providing them, which is important for creating public value (Fundusz ARC 2013, pp. 21-23).

The current guide on systematising innovation in the public sector, just like in business organisations, is the OECD methodology. There are four types of innovations: product, process, marketing and organisational. A product or service can be innovative. For services that are appropriate to the activities of public sector organisations, product innovations can consist in introducing significant improvements in the manner a service is provided, adding new functions or features to existing services or introducing completely new ones. Process innovations in the context of services concern new or significantly improved methods of their creation and provision. Marketing innovations may constitute new solutions in terms of methods of selling services to customers, while organisational innovations are related to the implementation of a new organisational method in the principles of operation adopted by an organisation, in the organisation of a workplace or in relation to the environment. The aim of organisational innovations may be, for example, increasing the level of job satisfaction or acquiring external knowledge.

A review of the subject literature allows for the identification of different types of innovations in the public sector (e.g. Kraśnicka 2009, Bloch 2011, De Vries, Bekkers \& Tummers 2016). T. Kraśnicka (2009, p. 67), invoking the paradigm of the so-called post-industrial innovation, where the social theme is exposed. Two types of innovation can be distinguished in the public sector: organisational and social. Organisational innovations are related to the internal functioning of institutions or the relations between them (e.g. new methods of management, communication, new structural solutions etc.), while social innovations are mainly related to broadly understood methods of satisfying social needs for specific public goods (e.g. new ways of providing public services). C. Bloch (2011, pp. VI-VIII) has introduced a new category - communication innovation (as opposed to marketing innovation), which focuses on the development of e-government and the impact of information and communication technologies on the intensification of innovation in the public sector. The most synthetic approach to the current typology of innovation in the public sector is presented by H. De Vries, V. Bekkers and L. Tummers (2016, p. 153). They identify four types of innovations: product or service innovations; process innovations (among which they distinguish administrative and technological innovations); governance innovations and conceptual innovations. Product and service innovations are understood as creating new services and products for stakeholders. Administrative process innovations include 
the creation of new organisational forms, the introduction of new management methods and techniques and new working methods. Technological process innovations include the development or use of new technologies for data processing, and the production of documents or collection of files necessary to provide services to users. Governance innovations concern the development or creation of new forms and processes for solving specific social problems. Conceptual innovations relate to the implementation of new concepts, frameworks or new paradigms that help to redefine the nature of specific problems as well as to introduce changes for solving them.

\section{Conditions at and Characteristics of an Innovative Public Sector Organisation}

Exploration of the concept of innovation in the public sector intensified at the beginning of the 21st century and still constitutes an interesting area of research globally (e.g. Miles \& Roste 2005, De Vries, Bekkers \& Tummers 2016, Moussa, McMurray \& Muenjohn 2018) and in Poland (e.g. Fundusz ARC 2013, GUS 2018a). A review of achievements to date leads to the conclusion that public organisations are innovative, but their innovation is conditioned by the specific nature of the public sector, which can be considered in terms of innovation characteristics, objectives and results, as well as drivers and barriers to innovation in a public organisation (Fig. 1).

The concept of innovation is the starting point for defining innovativeness. According to the terminology used by the Polish Central Statistical Office (GUS), based on the methodology of the OECD and the European Commission, innovative activity includes all scientific, technical, organisational, financial and commercial activities that actually lead or are intended to lead to the implementation of innovations. Some of these activities are innovative in themselves, while others are not new, but are necessary for the implementation of innovations (GUS 2018b, p. 6). An innovative company is perceived as a smart organisation that generates and implements innovations, while finding recognition among the recipients of its innovations due to its high level of modernity and competitiveness. Innovative companies should be characterised by the ability to permanently generate innovation and creativity while exhibiting the ability to use the innovative potential to maintain a high competitive position based on key competences. It should likewise be able to anticipate the future and remain in constant communication with the company's customers in order to effectively learn about their needs. It must also have a team of innovators who guarantee a high level of innovation and flexibility in adapting to changing conditions (Sosnowska 2000, pp. 11-12). 


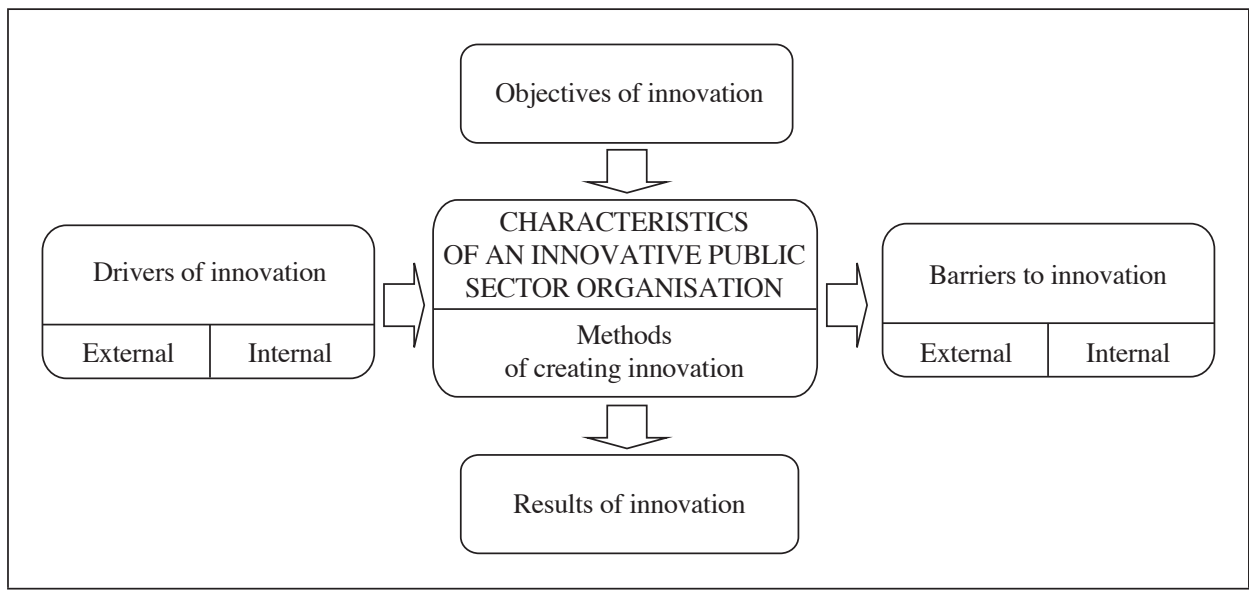

Fig. 1. Conceptual Model of an Innovative Public Sector Organisation Source: the author.

A. Arundel and H. Hollanders (2011, pp. 25-26) identify three methods of creating innovation in the public sector: a policy-driven approach, bottom-up initiatives and external sources. The first method is characterised by innovation created in response to changes in the budget, new regulatory provisions, policy priorities or the mandatory introduction of new services. It is characterised by little involvement of employees of public sector organisations in initiating or implementing innovation - their activity is only based on top-down obligations, while cooperation with the environment in obtaining information or involving stakeholders is very low.

The second method, the bottom-up approach to innovation, is the opposite of the policy-driven approach. Bottom-up innovators have active support for innovation management, which motivates them to develop innovative ideas, acquire new knowledge, test innovative solutions or participate in building new strategies. The last method, based on the acquisition of knowledge and solutions from external sources, is characteristic for organisations where the development of innovations is supported by the acquisition of information from providers and recipients of services, analysis of best practices, and the use of knowledge and experiences of other countries. Employees of such organisations are open to training and co-operation with third parties in Poland and abroad. The need to adapt to the current requirements of stakeholders, conditioned by the specific nature of functioning of the private or public sector, allows for the assumption that the characteristics of enterprise innovation are today universal and may become a determinant of innovativeness of public sector organisations (Table 1). Researchers have emphasised that the specific nature of public sector organisations significantly determines innova- 
tion in this area (e.g. Miles \& Roste 2005, Smith \& Starkey 2010, De Vries, Bekkers \& Tummers 2016, Moussa, McMurray \& Muenjohn 2018). They highlight both the drivers and the barriers to innovation in the sector. External drivers include the pressure of the environment related to the increasingly diverse and changing needs of a wide range of stakeholders, the development of ICT, the need to compete with other organisations both within the sector and with non-profit organisations and private entities, the pursuit of improved communication with stakeholders, participation in networks, stakeholder participation in management and transparency and accountability in the use of public funds.

Table 1. Characteristics of an Innovative Public Sector Organisation

\begin{tabular}{|l|}
\hline \multicolumn{2}{|c|}{ INNOVATIVE PUBLIC SECTOR ORGANISATION } \\
\hline \multicolumn{2}{|c|}{ Characteristics } \\
\hline - ability to generate innovation on a permanent basis \\
- creativity in the implementation of knowledge and new solutions \\
- adaptability \\
- ability to use innovative potential, based on key competences \\
- ability to foresee the future \\
- continuous cooperation with stakeholders in order to effectively learn about their needs \\
- having a team of innovators who guarantee a high level of innovation \\
- flexibility to adapt to the changing conditions \\
- modern management model \\
- focus on participation \\
\hline \multicolumn{2}{|c|}{ Methods of creating innovation } \\
\hline \multicolumn{2}{|c|}{ Policy-driven } & Bottom-up initiatives & Based on external sources \\
\hline
\end{tabular}

Source: the author, based on (Sosnowska 2000, p. 11; Zakrzewska-Bielawska 2011, p. 40; Arundel \& Hollanders 2011, pp. 25-26).

In terms of internal drivers, they emphasise a change in employees' attitudes, the development of a pro-innovative organisational culture, striving for learning and self-development, delegation of powers, empowerment of employees, a change of leadership, the introduction of modern systems of motivation and a focus on creativity and acceptance of innovations. Undoubtedly, barriers to innovation are also important, which at an exogenous level include political influence on decisions, short-term and limited budgets, social and public pressure (e.g. of the media), a lack of clear connection between innovation and constituents' support, legal conditions, rigid rules and procedures, an inability to focus on long-term benefits, ineffective cooperation with stakeholders and a low level of adaptation of new technologies. Endogenous factors include organisational culture that fails to foster innovations, outdated management models focusing on one-way communication, execution of orders, enforcing subordination, top-down dictates, as well as 
a lack of resources, resistance to change, aversion to risk and lack of competence in terms of change management.

In a recent study on innovation barriers in the public sector, E. Cinar, P. Trott and Ch. Simms (2019, pp. 271-277) distinguished four categories of barriers:

- organisational barriers (ineffective administration of process activities, resistance or lack of support from specific actor(s), lack of available resources, rigid organisational structure/culture, lack of skills/knowledge/expertise);

- interaction-specific barriers affecting interaction between partners within innovation (partners include: public sector organisations, citizens \& NGOs, businesses as contractors, political entities, businesses as users or co-creators, international organisations and other);

- barriers to innovation features (such as incompatibility, complexity, switching costs, lack of interoperability, platform/software problems, inflexibility and other);

- contextual barriers (such as laws, regulations, lack of standardisation, geography and other).

\section{Research Procedure}

In order to present the conditions of innovation of public sector organisations, public primary schools run by local government units in a large city in Małopolskie Voivodeship, Poland, were selected as the research subject. The study was conducted between April and June, 2019, using semi-structured direct interviews. The respondents were teachers from all professional rungs (trainee, contract teacher, appointed teacher, certified teacher); while the schools involved all gave their consent to the research. School principals were also invited to the study, but they selected teachers for the study. Initially, queries were directed to 40 teachers in five schools. Four primary schools participated in the research and 17 teachers were interviewed, with 17 teachers agreeing to participate in the study. The activity of primary schools in Poland is regulated by the Education Law of 14 December 2016, as amended (Dz.U. of 2017, item 59). Primary schools educate students, who are subject to compulsory education in grades I to VIII.

The research was a preliminary diagnosis of the problem, with no statistical analysis involved. The aim of the study was to learn the teachers' opinions about innovative measures implemented in the primary schools where they were employed. In particular, the teachers were asked to interpret the term "innovation", focusing on the objectives of introducing innovations at school; to characterise examples of innovations within the proposed typology; to indicate the sources of creating and financing innovations at school; to outline how they shared new 
ideas; and to specify factors that motivate teachers to generate innovations and barriers to their implementation.

For the purposes of the study, a broad definition of innovation was adopted, according to which innovation means changing, enriching one's environment with new components, deliberately and consciously introducing something new that is better, more perfect and contributes to progress under the circumstances. Innovation must be useful, provide a positive assessment in the light of specific criteria, be a qualitative change different from already existing solutions that have been implemented and accepted by the market (Moszkowicz 2006, pp. 45-53). Educational activities are treated as services on the assumption that service innovation should be characterised by (Osiadacz 2012, p. 39): the creation of new or improved services, the use of new or improved methods of providing service, the application of a new way of interacting with customers and suppliers, opening a new market for the provision of service, the use of new materials or tools or the introduction of changes in organising the provision of service. The OECD's classification of types of innovation was adopted, including communication (instead of marketing) innovation, in line with the concept of C. Bloch (2011). The analysis presents the respective components comprising part of the research model presented in Figure 1.

\section{Presentation of the Results of the Study}

Only women aged 27-65 participated in the study, of whom 5 were 27-35 years of age, 6 were $36-45,3$ were $46-55$ and one was 56-65. Respondents were employed schools as: a trainees (2 individuals), contract teachers (3), appointed teachers (3), a certified teachers (7).

The importance of innovation for the development and competitiveness of the schools has increased significantly in recent years, along with demands relating to the need to revise and reformulate the way public sector organisations operate. The first question in the study concerned the interpretation of the term "innovation".

Respondents most often associated innovation with "the implementation of new, better solutions" and with "a new idea, product/service/facilitating process" as well as with "a new approach to an issue". Moreover, innovations used "new opportunities" or "a new organisational solution" or "a new way of solving a problem". For the majority of respondents, innovation was closely related to the implementation of new solutions for products, services or processes.

As the presentation of objectives shown in Figure 2 illustrates, improving the school's image and extending the current teaching offering were the two most important issues for teachers. Those aspects were extremely important from the point of view of competition on the local market, where primary schools were also 
run by private entities and church organisations. Further objectives included the initiative of staff and management, the improvement of the teaching process and the expectations of parents and students. Occasionally, the indicated objectives included the willingness to acquire new partners for cooperation or to obtain or change the structure of the school's budget.

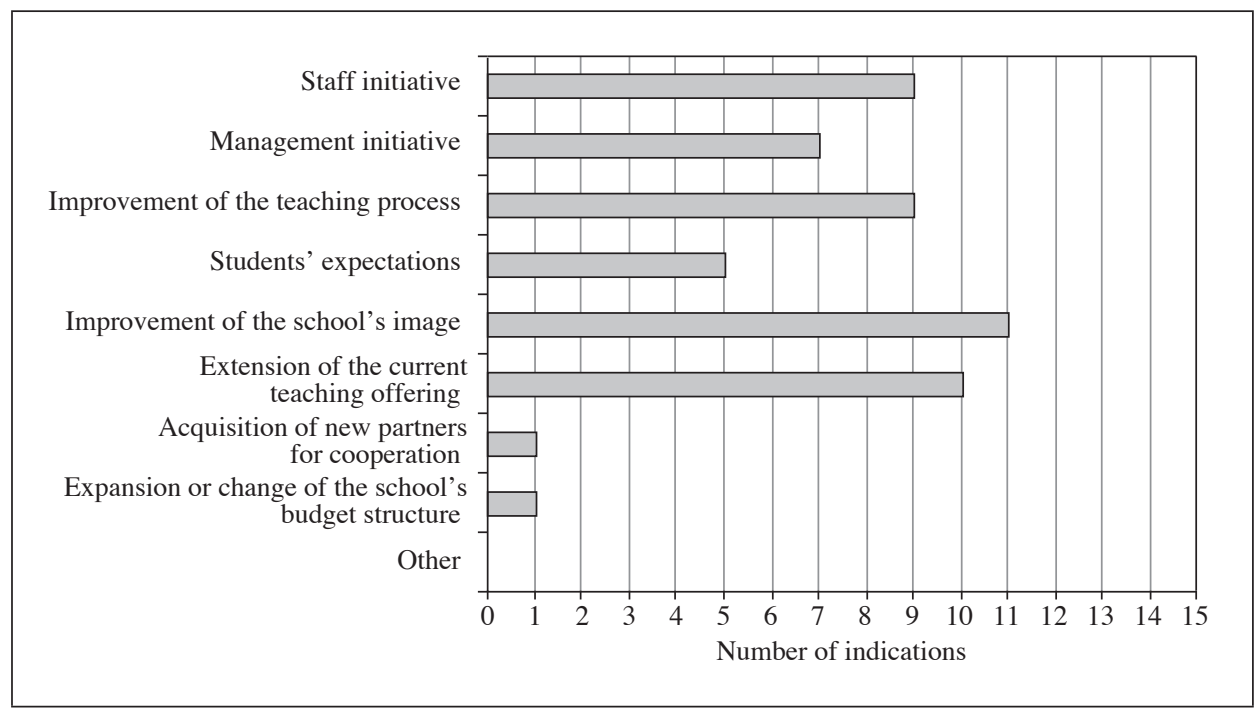

Fig. 2. Innovation Objectives in Primary School

Source: the author.

Another issue raised in the interview was the identification of methods of creating innovations in the schools (Fig. 3). In this respect, teachers' bottom-up initiatives, indicated by the majority of respondents and supported by the management, prevailed. Further sources of innovation could be attributed both to policy-driven methods, with measures resulting from changes in legal regulations, and to methods based on the use of external sources. The third way of creating innovations involved acquiring knowledge during conferences and trainings, using benchmarks employed in private schools, and developing new strategies to adapt to the changing environment and expectations of stakeholders.

When characterising the ways new ideas could be shared, the respondents indicated that ideas were directly submitted to the headmaster or headmistress, discussed during staff meetings or during informal meetings. They also reported that innovation teams had been organised at school, albeit very rarely, as had an idea box, once. At the same time, teachers stressed that most often they initiated and implemented innovations on their own and they were often supported and 
supervised by the headmaster/headmistress. Only one respondent took part in the works of the team appointed at school specifically to implement innovations.

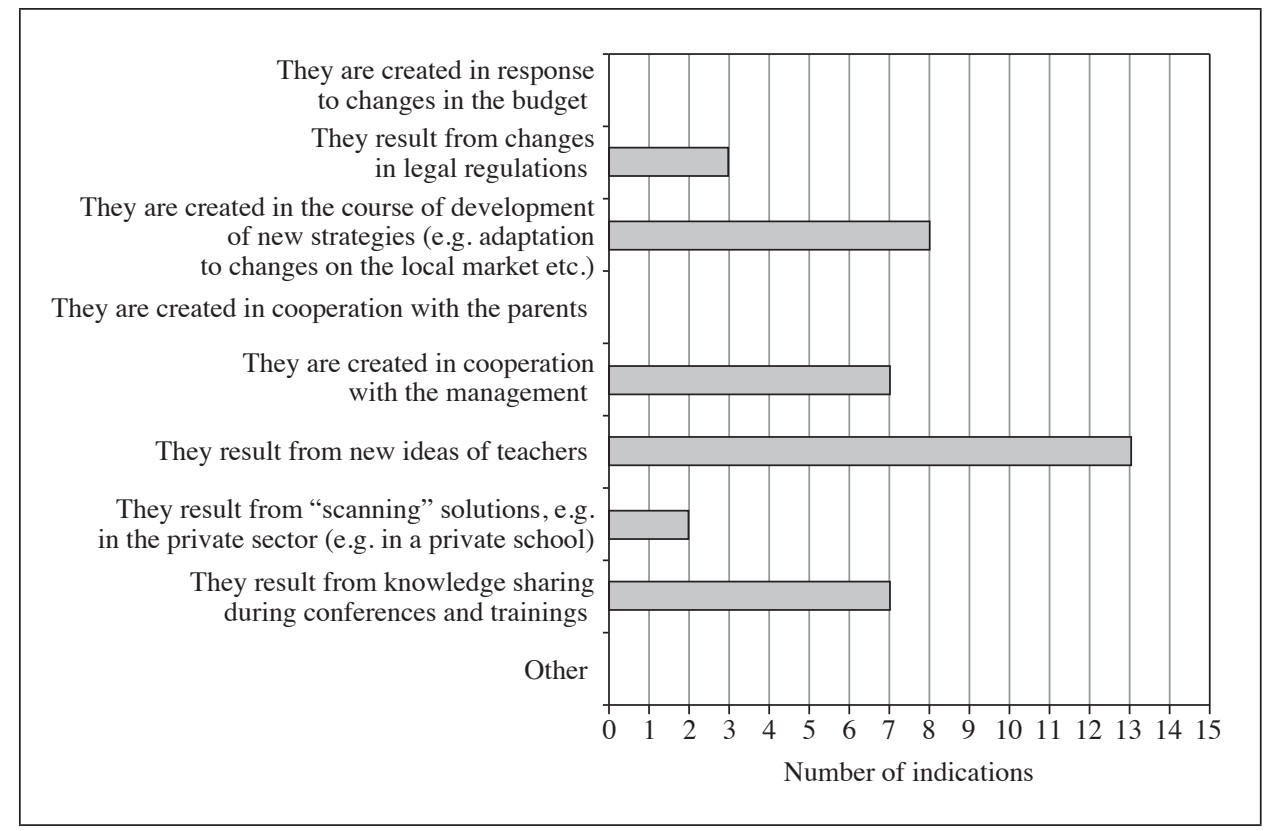

Fig. 3. Innovation Sources in Primary School

Source: the author.

Among the factors driving the search for and implementation of innovations in the schools, the most frequent responses were the possibility of personal career development and promotion, followed by access to new knowledge and information and subsequent improvement of the teaching process through the introduction of a new teaching method or method of conducting classes. An improvement or change in how work was organised and recognised or commendation by a superior were then indicated as equivalent. Other factors motivating teachers to undertake innovative activities included the prospects of additional remuneration and the possibility of active participation in a project. The improvement of working conditions was indicated as an additional motive.

As a result of the survey, the respondents, by referring to the proposed typology, indicated the solutions they attributed to a given type of innovation (Table 2). The proposed solutions of an innovative nature concerned the period "in the last 5 years". Among product innovations, new products within the teaching offering prevailed. One notable innovative solution was the introduction of a new type of extracurricular activity in one school - the Rugby Tag game, designed to help 
students acquire and develop emotional resistance. Another interesting solution was the introduction, in another school, of an additional mandatory subject in grades I-III - social education, developed by teachers. During the class, teachers talked with younger students about emotions, values and group behaviour. They indicated the class was well-received both by children and by parents, as it often provided additional space for solving group and individual problems, helped identify needs and develop relationships among students and between teachers and students. An interesting innovative solution that had been introduced in the last two years in each of the analysed schools was teaching Polish as a foreign language to foreigners. It resulted from the current need to adapt a growing number of children of foreigners to the primary school curriculum in Poland. The programme was co-financed by the local government administration.

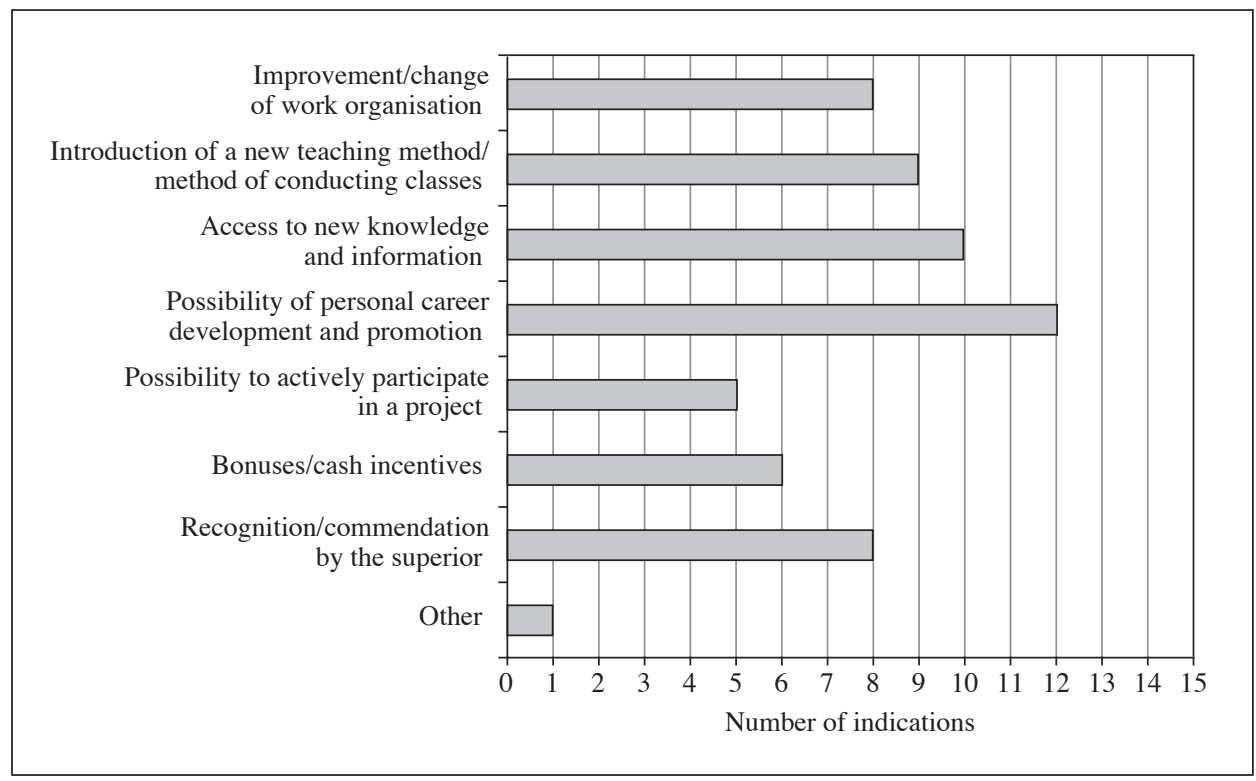

Fig. 4. Drivers for Generating Innovation in Primary School

Source: the author.

The distinguished process innovations, such as discussion forum or online management of the students' database, result from the increasingly higher level of implementation of modern information and communication technologies in the schools. Among the organisational innovations, new forms of conducting classes and preparing proprietary curricula prevailed. Introduction of formative assessment in maths classes in one of the schools was noteworthy. A method of teacher and student work developed in the UK, formative assessment consists in the systematic 


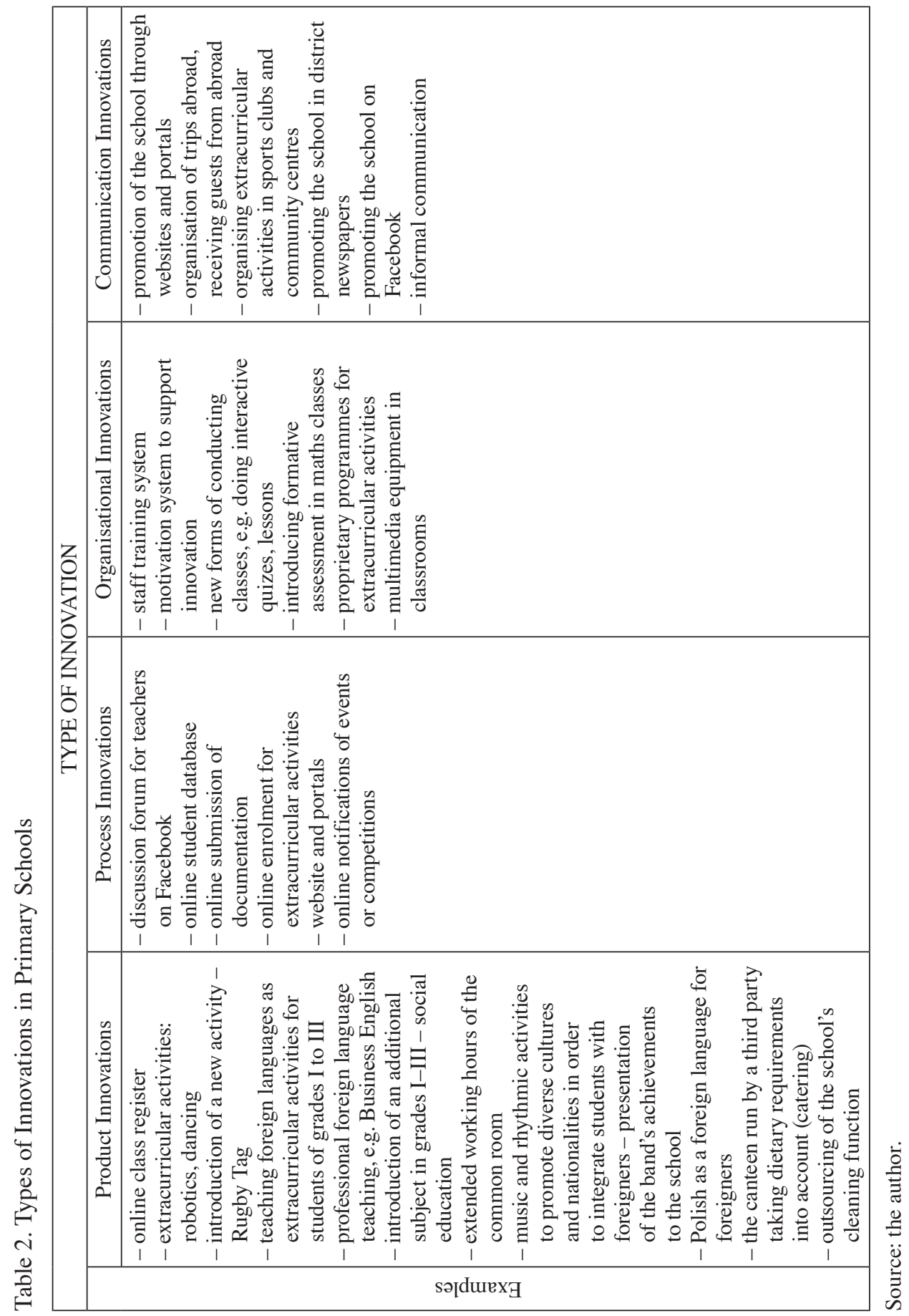


acquisition of information on the course of the learning process and introduction of a self-assessment component in work with students. It allows the teacher to modify further teaching and to offer feedback to students to help them learn. Introduced last year in all grades, this programme was very well-received by students, who appreciated the self-assessment component that inspired them to learn.

The teachers were likewise very positive about the staff training activities initiated by the school in response to changing legislation and regulations. Participation in the training allows teachers to improve their professional competences and to acquire new skills on a regular basis; it is also part of the motivation system.

The communication innovations indicated in the study primarily focused on promoting the school in a competitive environment both on the local market (direct participation, Internet, local press, informal communication) and abroad (organising trips abroad, receiving guests from abroad).

The last question concerned the identification of barriers in the process of initiating and implementing innovations in the schools (Fig. 5).

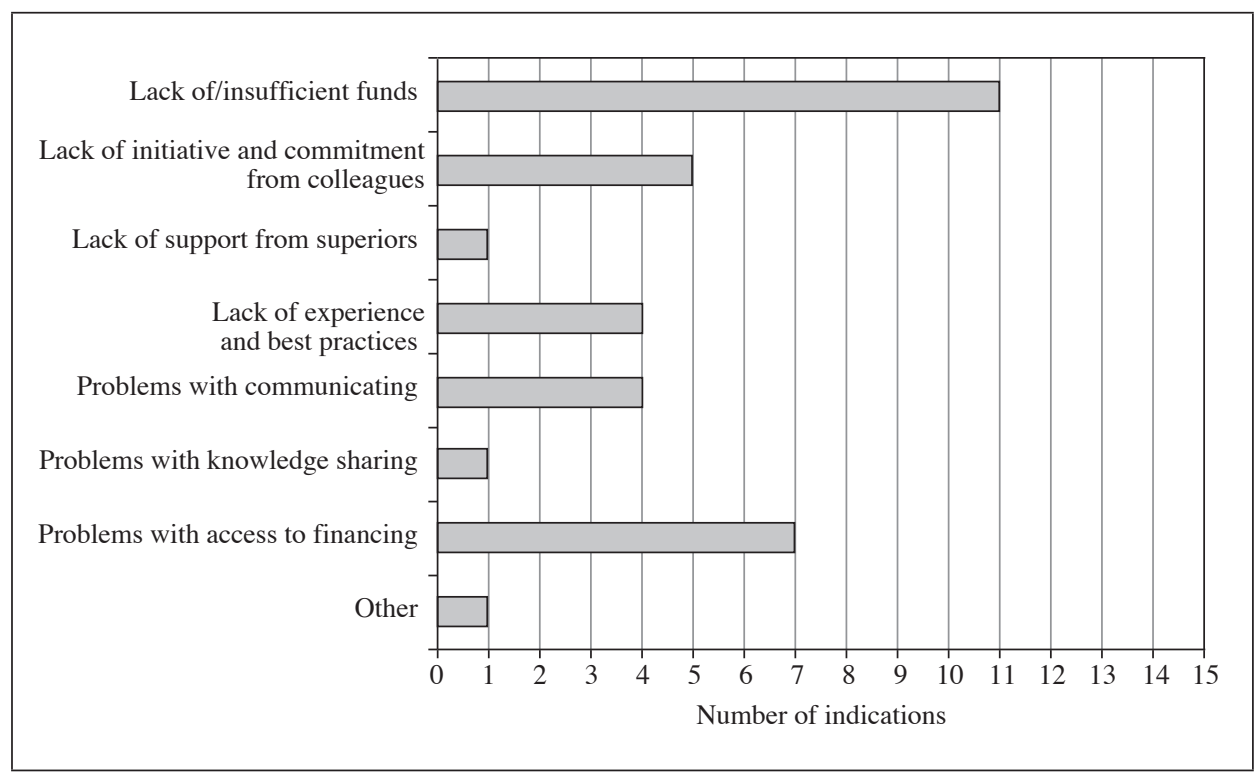

Fig. 5. Barriers to Innovation in the Analysed Primary Schools Source: the author.

The most frequently mentioned factors hindering innovative activities were a lack of funds and problems with gaining access to financing. In this respect, the respondents stressed that most often the implementation of innovations was financed from the school's budget, though for certain solutions schools could count 
on support from local authorities (e.g. subsidies, grants) and parents interested in improving the teaching process. To a great extent, proprietary solutions were also financed by the teachers from their own resources. Other barriers to innovation included a lack of initiative and commitment on the part of colleagues, problems with communication, a lack of experience and best practices and occasional problems with knowledge sharing, insufficient support from superiors and a lack of time due to a heavy workload (opinion of 1 respondent).

Although those barriers hindered innovative activities, the search for new solutions and their implementation was a constant process, and the surveyed teachers perceived them as a factor in the school's competitive advantage, and thus stabilisation of employment and an essential component for further development.

The analysis should be expanded to show how primary schools in small towns function as compared to their urban counterparts. Furthermore, the role and importance of teachers in implementing innovation in schools depending on their professional level and position held should also be explored. The results of the study presented in the article may be a source of knowledge for teachers, parents and students of primary schools in Poland. The specific innovative solutions implemented in the schools surveyed for this study, which stimulate students to engage and stimulate such features as creativity, self-esteem, willingness to develop and search for new knowledge, are particularly valuable. The search for other original solutions is a further, worthwhile area of research.

\section{Conclusion}

Assessment of the nature and importance of innovative activities in the development of public sector organisations on the example of primary schools leads to the conclusion that the challenges in this respect are currently both desirable and necessary. While in enterprises the effects of innovation are most often associated with financial results, in the case of schools the results of innovation are considered in the context of social effects related to satisfaction and fulfillment of stakeholder expectations - those of both students and their parents. They also translate into a higher quality teaching process, which increases the satisfaction and comfort of teachers. The teachers surveyed represent huge innovative potential, which is necessary for a school to develop and to maintain its position on the volatile and competitive market for educational services. Measuring and evaluating innovation in the public sector is a difficult and complex task, as the expected results in social evaluation relate to the improvement of the teaching process, which is very difficult to define. That is because it contains many values, is conditioned by various factors, and its effects are intangible. I believe the perceived high level of support for innova- 
tion in the schools analysed, expressed by a high level of commitment of employees who are proactive and creative, take advantage of opportunities, face up to new challenges, build relations and a culture conducive to innovation, combined with the simultaneous involvement and support of the management, justifies the assumption that the innovativeness of public sector organisations should be evaluated.

The concrete and orderly characterisation of the solutions employed in the primary schools allow us to conclude that both the teachers and the management are aware of the importance of innovations not only in building the position of the school on the market of educational services, but also in teachers' personal development. The innovation policy in the schools is generally known, teachers are inspired to seek and implement innovations, and the attitude of the management in the majority of cases stimulates teacher creativity, which is additionally supported by tangible or intangible incentives, e.g. commendations or awards from management and higher-ups. New ideas and solutions undoubtedly improve the teaching process, which is appreciated both by students and their parents. In the primary schools participating in the study, the most important sources of innovation were the teachers, their level of knowledge, competence, creativity, commitment and personality. The innovativeness of the teachers results from a variety of incentives, the most important of which are the possibility of personal development, a willingness to pursue career development, improvement of work organisation or access to new knowledge and information. Undoubtedly, the results of the study allow us to conclude that there are conditions supporting innovative activities in the schools. The schools proved highly adaptible and flexible in the context of the changing expectations of stakeholders and conditions. They constantly cooperated with the environment in order to identify needs on a regular basis, they had great potential in staff that was competent and open to innovation, they applied a modern management model with a high degree of employee participation and they accurately and thoroughly analysed current trends. This proves anticipation of the future and awareness of the importance of innovation in further development and the maintenance of their competitive position on the market.

Undoubtedly, the presented results have numerous limitations. They result mainly from the pilot nature of the survey and its limited scope (only selected teachers from four primary schools, from a large city in Małopolskie Voivodeship, willing to participate in the survey, were interviewed). The results, therefore, cannot be generalised and their analysis should be approached from a critical perspective. The research requires further elaboration and to be based on a representative research sample. The context of the study of innovation in the area of primary schools, when there is a clear need for changes in the education sector, is important and insufficiently recognised in Poland. Continuing the analysis will bring about additional research challenges. 


\section{Bibliography}

Arundel A., Hollanders H. (2011), A Taxonomy of Innovation: How Do Public Sector Agencies Innovate? Results of the 2010 European Innobarometer Survey of Public Agencies, European Commission, Maastricht, https://eprints.utas.edu.au/12552/1/A_ taxonomy_of_innovation.pdf (accessed: 6.10.2019).

Ayvaz Can A. (2020), Examination of the Relationship between Individual Innovativeness Levels and Professional Innovativeness Tendencies of Primary School Teacher Candidates, "Malaysian Online Journal of Educational Technology", vol. 1, no 8, https://eric.ed.gov/?id=EJ1239959 (accessed: 6.10.2019).

Bloch C. (2011), Measuring Public Innovation in the Nordic Countries (MEPIN), Nordic Innovation Centre, Oslo, http://nyskopunarvefur.is/files/filepicker/9/201102_mepin_ report_web.pdf (accessed: 6.10.2019).

Ciascai L., Șuteu L., Cristea M. (2019), Students Future Teachers for Primary Schools Opinion about the University Openness towards Innovation, "Acta Didactica Napocensia", vol. 12, no 2, https://doi.org.10.24193/adn.11.2.4.

Cinar E., Trott P., Simms Ch. (2019), A Systematic Review of Barriers to Public Sector Innovation Process, "Public Management Review", vol. 21, no 2, https://doi.org.10.108 0/14719037.2018.1473477.

De Vries H., Bekkers V., Tummers L. (2016), Innovation in the Public Sector: A Systematic Review and Future Research Agenda, "Public Administration", vol. 1, no 94, https://doi.org/10.1111/padm.12209.

Drucker P. F. (1992), Innowacja i przedsiębiorczość. Praktyka i zasady, PWE, Warszawa.

Fundusz ARC (2013), Innowacje w sektorze publicznym. Raport przedstawiajacy aktualny stan wiedzy Fundusz na rzecz Badań Stosowanych i Komunikacji, Sofia, http:// europa.um.warszawa.pl/sites/europa.um.warszawa.pl/files/zalaczniik_2_raport_wersja_bazowa_13_02.pdf (accessed: 6.10.2019).

GUS (2018a), Badanie innowacji w wybranych jednostkach administracji publicznej w Polsce. Prace eksperymentalne, Główny Urząd Statystyczny, Warszawa, https://stat. gov.pl/statystyki-eksperymentalne/badania-i-rozwoj-innowacyjnosc-spoleczenstwo-informacyjne/badanie-innowacji-w-wybranych-jednostkach-administracji-publicznej,3,1. html\# (accessed: 6.10.2019).

GUS (2018b), Działalność innowacyjna przedsiębiorstw w latach 2015-2017. Informacje sygnalne z 29.10.2018, Główny Urząd Statystyczny, Warszawa, https://stat.gov.pl/ download/gfx/portalinformacyjny/pl/defaultaktualnosci/5496/14/5/1/dzialalnosc_innowacyjna_przedsiebiorstw_w_polsce_w_latach_2015-2017.pdf (accessed: 6.10.2019).

Hood Ch. (1991), A Public Management for All Seasons?, "Public Administration", vol. 69, no 1, https://doi.org/10.1111/j.1467-9299.1991.tb00779.x.

Klinger M. B. (2004), Innovation in Education: The Concept of Radical Innovation Adoption, "Estonian Business School Review", no 18.

Kraśnicka T. (2009), Przedsiębiorczość sektora publicznego i jej uwarunkowania (in:) A. Frączkiewicz-Wronka (ed.), Zarzqdzanie publiczne - elementy teorii i praktyki, Wydawnictwo Akademii Ekonomicznej im. Karola Adamieckiego w Katowicach, Katowice.

Miles I., Roste R. (2005), Differences between Public and Private Sector Innovation (in:) T. Halvorsen, J. Hauknes, I. Miles, R. Røste (eds), Innovation in the Public Sector: Public Report No. D9 on the Differences between Public and Private Sector Innova- 
tion, NIFU STEP, Oslo, http://unpan1.un.org/intradoc/groups/public/documents/apcity/ unpan046809.pdf (accessed: 6.10.2019).

Moszkowicz M. (2006), Przedsiębiorczość i innowacyjność w gospodarce opartej na wiedzy (in:) K. Jaremczuk (ed.), Uwarunkowania przedsiębiorczości - aspekty ekonomiczne $i$ antropologiczno-społeczne, PWSZ w Tarnobrzegu, Tarnobrzeg.

Moussa M., McMurray A., Muenjohn N. (2018), A Conceptual Framework of the Factors Influencing Innovation in Public Sector Organizations, "The Journal of Developing Areas", vol. 3, no 52.

Mykhailyshyn H., Kondur O., Serman L. (2018), Innovation of Education and Educational Innovations in Conditions of Modern Higher Education Institution, "Journal of Vasyl Stefanyk Precarpathian National University", vol. 5, no 1, https://doi.org10.15330/ jpnu.5.1.9-16.

OECD (2018), Oslo Manual: Guidelines for Collecting and Interpreting Innovation Data, 4rd ed., OECD, Paris, https://www.oecd.org/science/oslo-manual-20189789264304604-en.htm (accessed: 6.10.2019).

Osborne S. P. (2006), The New Public Governance?, "Public Management Review”, vol. 8, no 3, https://doi.org/10.1080/14719030600853022.

Osiadacz J. (2012), Innowacje w sektorze ustug - przewodnik po systematyce oraz przykłady dobrych praktyk PARP, Warszawa, https://www.parp.gov.pl/files/74/81/545/20507. pdf (accessed: 6.10.2019).

Schumpeter J. (1960), Teoria rozwoju gospodarczego, PWN, Warszawa.

Smith M. A., Starkey A. P. (2010), The Utilisation of Private Sector Governance Paradigms for the Development and Implementation of Innovations in the Public Sector, "International Journal of Innovation Science", vol. 2, no 3, https://doi.org.10.1260/17572223.2.3.103.

Sosnowska A. (2000), Systemy zarzqdzania firmq innowacyjnq (in:) A. Sosnowska, S. Łobejko, A. Kłopotek (eds), Zarzqdzanie firmq innowacyjnq, Difin, Warszawa.

Vincent-Lancrin S., Jacotin G., Urgel J., Kar S., González-Sancho C. (2017), Measuring Innovation in Education 2019: What Has Changed in the Classroom, Educational Research and Innovation, OECD Publishing, Paris, https://doi.org/10.1787/9789264311671-en.

Zakrzewska-Bielawska A. (2011), Ocena innowacyjności małych i średnich przedsiębiorstw sektora ICT (in:) A. Zakrzewska-Bielawska (ed.), Wyzwania rozwojowe małych i średnich przedsiębiorstw. Innowacje, technologie, kryzys, Difin, Warszawa.

\section{Uwarunkowania innowacyjności organizacji sektora publicznego na przykładzie wybranych szkół podstawowych}

(Streszczenie)

Cel: Cel artykułu stanowi prezentacja i analiza wyników badań pilotażowych w zakresie diagnozy i oceny uwarunkowań innowacyjności organizacji sektora publicznego na przykładzie wybranych szkół podstawowych, funkcjonujących na terenie dużego miasta w województwie małopolskim.

Metodyka badań: Część teoretyczną artykułu oparto na studiach literaturowych, krajowych i zagranicznych. Badania pilotażowe przeprowadzono za pomocą wywiadu kierowanego, częściowo ustrukturyzowanego, przeprowadzonego z 17 nauczycielami z 4 szkół 
podstawowych z województwa małopolskiego. Niewątpliwie zaprezentowane wyniki mają wiele ograniczeń. Wynikają one przede wszystkim z pilotażowego charakteru przeprowadzonego badania i jego ograniczonego zakresu (wywiady przeprowadzono jedynie wśród wybranych, chętnych do uczestnictwa w badaniu nauczycieli tylko czterech szkół podstawowych, z terenu dużego miasta w województwie małopolskim). Zatem wyników tych nie można uogólniać, a ich analiza powinna mieć charakter krytyczny.

Wyniki badań: W badanych szkołach zarówno nauczyciele, jak i kadra zarządzająca mają świadomość znaczenia innowacji w kształtowaniu pozycji szkoły na rynku usług edukacyjnych, jak też faktu, że stanowią one kluczowy czynnik rozwoju osobistego nauczycieli. Polityka innowacji w badanych szkołach jest powszechnie znana, nauczyciele są inspirowani do poszukiwania i wdrażania innowacji, a postawa dyrektorów pobudza kreatywność nauczycieli, co dodatkowo wpierają bodźce materialne w postaci nagród lub niematerialne, np. pochwała czy wyróżnienie ze strony przełożonego.

Wnioski: Nowe pomysły i rozwiązania niewątpliwie usprawniają proces dydaktyczny, co doceniane jest przez uczniów i rodziców. W szkołach podstawowych uczestniczących w badaniu najważniejszym źródłem innowacji są nauczyciele, ich poziom wiedzy, kompetencje, kreatywność, zaangażowanie oraz cechy osobowościowe.

Wkład w rozwój dyscypliny: Badania problemu innowacyjności w obszarze szkół podstawowych, w dobie artykułowania konieczności zmian w sektorze edukacji, są ważne. Jest to problem niewystarczająco rozpoznany w polskich warunkach. Perspektywa wzbogacenia przeprowadzonej analizy może stanowić kolejne wyzwania badawcze.

Słowa kluczowe: innowacyjność, organizacja publiczna, szkoły podstawowe, wywiad kierowany. 